\title{
Educational Programmes as Key Variable Towards Change of Behavior Among Inmates in Correctional Facilities in Kenya
}

\author{
Solomon Gikundi Koome ${ }^{1}$, Charles Misiko Wafula ${ }^{2}$, Raphael Ondeko Nyonje ${ }^{3}$ \\ 1.Correctional Officer, State Department of Correction Service. P.O Box 30195-00100 Nairobi- Kenya \\ 2.School of Open and E-learning, University of Nairobi P.O Box 30197-00100 Nairobi- Kenya \\ 3.School of Open and E-learning, University of Nairobi P.O Box 30197-00100 Nairobi- Kenya
}

\begin{abstract}
This study focused on influence of educational programmes on change of behavior of inmates in correctional facilities in Kenya. The study was based on the following objective; to examine how educational programmes reforms influences change of behavior of inmates in correctional facilities in Kenya. The study tested an alternate hypothesis on whether the relationship among the study variable was significant. The target population was 10,111 individuals spread as 2,953 prison officers and 7,158 inmates. From this population a sample was drawn using a formula totaling to 385 individuals who were picked for the study. The sample was spread accordingly as 112 prison officers and 273 inmates. Purposive sampling was used to select officers' in-charge and their deputies. Twelve prison officers on duty were picked randomly from duty roster using prime numbers for focus group discussion from each prison. A separate list of long term prisoners was compiled from the records of capital offence and other offences who have served jail term of over ten years or have been in remand for ten years and then the sample size was picked in proportionate to the population in each prison institution from the list. Primary data was gathered by a semi-structured questionnaire, an interview schedule and focus group discussion from the target population. Secondary data was gathered through analyzing relevant documents. The study incorporated quantitative and qualitative approaches to process, analyze, and interpret the data. The SPSS was applied to run analyses for percentages, frequency distributions, and measures of central tendency. Descriptive statistics were computed for variable using frequencies, percentages, mean and standard deviation. Statistical tools used for inferential statistic were person's product moment correlation(r), simple regression, multiple regression and step wise regression $\left(\mathrm{R}^{2)} \mathrm{T}\right.$-tests were used to test hypothesis in the study the results revealed that $\mathrm{r}=0.425, \mathrm{t}=7.129$, at $\mathrm{p}=0.000<0.05, \mathrm{H}_{1}$ was confirmed and concluded that educational programmes reforms, had a statistically significant influence on change of behavior of inmates in correctional facilities in Kenya. Findings of the study are expected to be crucial to government policy makers regarding formulation and implementation of the prison reforms. The serving inmates may benefit from the improved prison environment which will be aligned with market preference and whose content may benefit the community.
\end{abstract}

Keywords: Educational programmes, change of behavior, inmates, correctional facilities.

DOI: $10.7176 /$ PPAR/9-11-05

Publication date: November $30^{\text {th }} 2019$

\subsection{INTRODUCTION}

Since the conception of the modem state, prison reform has been an issue raising national and international concern. Prisons worldwide are faced with the problem of adjusting their attitude and adapting a proactive system in order to attain their goals and objectives (Prison handbook, 1997). Prisons serve a valuable role in society, by providing a rehabilitative environment for those who break the rule of law in an effort to better them as people. They encourage peace and allow for reform (Adler and Longhurst, 1994). Prison reform in Germany is geared towards deterrence, reformation, and the protection of society. These factors are emphasized differently in different countries. Emphasis has been laid chiefly upon punishment and the protection of society. Empowerment of officers through education is manifested through numerous libraries found in most prisons (Anderson and Overy, 2010).

The duty of societies is the care of the family of the prisoner during imprisonment (Austin, Baird and Neuenfeldt, 2008). In India various workshops had been organized by the state government in collaboration with NGO's to bring reforms in the current prison systems (Danielsen and Balmford, 2003). Many reforms have been made in jail administration to provide an enabling environment for rehabilitation of inmates and providing meaningful educational facilities for inmates if they are employed after release and for that purpose should be introduced or upgraded. The open prison system has come as a very modern and effective alternative to the system of closed imprisonment. The establishment of open prisons on a large scale as a substitute for the closed prisons, the latter being reserved for hardcore criminals shall be one of the greatest prison reforms in the penal system (Anderson \& Overy, 2010). Central government along with NGO's and prison administration has taken adequate steps for effective centralization of prisons. The uniformity of standards has been maintained throughout the states which has enabled in changing the traditional and colonial outlook of the Indian prison 
system and also helped the prisoners to become more responsible, creative and potential citizen (Bayens, Williams, and Smykla, 2012). In South Africa, prison reforms have been spearheaded by United Nations bodies like UNODC which assists states in developing strategies to reform all aspects of their criminal disputes between the prisoner and the state in many of these contact areas because states frequently cannot muster sufficient political will to act constitutionally and provide inmates with the minimal standards life's necessities, such as decent food, shelter, medical care, and physical safety (Chapman, 2013).

According to International Covenant (2010) parties agreed that education shall aim at fully developing human personality and the sense of its dignity, as well as strengthening respect for fundamental freedoms and human rights. They are also in agreement that provision of education shall empower all people to participate effectively in a free society, enhance understanding, promote tolerance and friendship amongst all nations, races, ethnic or religious groups, and maintain peace (Cole, 2002).

With a view of achieving full realization of this basic right, access to primary education shall be compulsory and freely availed to all persons and secondary education in its different forms, such as vocational and technical, shall be availed generally and accessed by all, based on their capacity (International Covenant, 2010). The articles further state that college education shall be made accessible on equal standing to all on the basis of learners capability by every possible means, and particularly by progressively introducing and supporting free education. Fundamental education shall be intensified and encouraged to enable persons who have not completed the whole period of their primary education to be able to do so and as such, material conditions of teaching staff shall be continuously improved (Kiira, 2014).

Every young offender of necessary school age has basic right to access to education suited to his or her ability and need designed in preparation for their return to society. Juvenile education must be provided outside the confinement facility in community schools if probable and, should be done by qualified teachers if possible through programs integrated with the education system of the country to allow the juvenile to continue with their education without difficulty upon release. Special consideration should be accorded when administering juvenile education to young offenders with particular ethnic or cultural needs and those with foreign origin. Further consideration should be accorded to illiterate young offenders and offenders with cognitive and learning difficulties, who should be provided with special education (Mutuma, 2015).

Education is an important medium for inculcating positive values, supportive of the rehabilitation and reform of prisoners. Through the education, prisoners acquire skills and knowledge which they can use to secure gainful employment and reintegrate into society. It also provides opportunities for outsiders to meet and teach prisoners. The Standard Minimum Rule on treatment of offenders 51 requires prison administration to provide education to inmates (who require it) and integrate inmates into country's education system upon release.

There exists little literature on status of education and training for prisoners in Kenya prior to 2003. From interviews conducted, it emerged from the study that prisons offered convicted prisoners adult education classes and formal education up to primary level in few prisons. Naivasha maximum prison offered accountancy courses with support from missionaries. Instruction is carried out by prisoners on a voluntary basis. However, prisons rely on donations from charities or instruction materials (Oketch, 2009).

Education and vocation training for offenders is one of the areas which has benefited immensely from the open door policy in the post 2003 period. Most of the prisons visited had initiated education programs for offenders. In Nakuru prison for instance; convicts have the best access to education up to primary (standard eight) level. Naivasha maximum prison continues to have the best education program for the prisoners in the whole country. In 2004, the prison offered candidates for the secondary level examinations for the first time. The prison has expanded its post-secondary education program by entering into a collaboration arrangement with Strathmore University (Nyaura and Ngugi, 2014). The prisons education program is run through an elaborate and autonomous leadership and management structure comprising prisoners.

Owing to the open door policy, well-wishers have shown considerable interest in the program by donating reading materials, stationary and computers. In Bomet prison, for instant, the local Kenya Commercial Branch $(\mathrm{KCB})$ donated funds and materials for the establishment of training workshop for the inmates. However, heavy reliance on donations places prisons in remote areas at a disadvantage as they attract few donors. According to Omoni and Ijeh, (2009) many prisoners continue to suffer from lack of books and other basis infrastructural requirements for education. This has severely discouraged even the few that are inclined to learn from or educate fellow prisoners.

Imprisonment is much more than just opening and closing the guarded prison gates. Contemporary penal management practices emphasize on reforming the convicts or the inmates. Despite the advancement on economic, democratic and political reforms, penal that is reasonable to convicts during and after imprisonment; hence a need to be rational and logical with the punishment. Austin, Baird and Neuenfeldt (2007) further stressed this position that crime that gave pleasure should be counteracted by pain (imprisonment) which should be applied reasonably. McCorkle and Korn (2004) argued that illiteracy and criminal activities are sometimes intertwined. They further stressed on the need of introducing educational 
programmes to prisons that could help inmates gain skills and competence to penetrate job market upon release which can be made possible by efforts of qualified and motivated prison instructors.

Without effective program to assist offenders face these multiple challenges, the likelihood of successful rehabilitation is very poor hence there is a need to impact the prisoners with necessary skills that will be helpful to them and the community at large. This view stem from the understanding that persons who have acted against laws and society's' collective norms articulated in criminal laws should be rehabilitated; hence the application of the term correction to echo this thinking (Ostreicher, 2003). Prisoners' connection with their families is very important to rehabilitation, in this regard, some prison institutions are running open days, events that attract family visit and contact with community members. The event and other simple programs such as remote parenting programmes for mothers in prison can help prisoners rebuild their social networks and stay connected with their families and community (Sarah, Gyn, \& Jonathan, 2016).

The detention centres is a component of criminal justice system entrusted institutionally to imprison, reform or rehabilitate lawbreakers and make sure that they abide by the principal society values on discharge. Convicts are therefore expected to access training, proper guidance and counseling and enabled to resocialize as better citizens (Odigha, 2004). Prison welfare officers have a general responsibility of staff and prisoner welfare who theoretically support the process of rehabilitation but in the Kenyan scenario they are too few, poorly equipped and trained to facilitate post release planning and prisoners contact with families and communities (Oketch, 2009). There is therefore a need to review their roles and functions towards rehabilitation and reintegration of offenders and need to recruit more welfare officers and equip them with skills on behavior modification techniques, counseling, and awareness of special needs of offenders. Pre-release planning and management of offenders' re-entry in the society as far as receiving the skills they require can be facilitated by the welfare officers (IED, 2004).

According to Kayode and Olusegun (2014) both prison inmates and prison staff have positive attitude towards rehabilitative counseling and inmates' educational attainment. They further stress that a significant difference between the attitudes of prison officials and prisoners as members of prison institution lies on the basis of their prison standings in most prisons. However there is a feeling that the depth of burden placed upon prisoners will call for mentoring and support to gain confidence and develop long term skills. Success will only be achieved as a result of team effort (Murtagh, 2006). The agenda for change, that involves, matters like privatization of services and resources should be embraced if meaningful prison reform outcome is to be realized. Considering the advice of experts from outside the prison service together with views of key prison service officials regarding reforms, assessment of the possibilities for successful change also need to be considered (Hooks et al., 2010).

Kenya Prisons Service functions are to contain and keep offenders in safely in custody, rehabilitate and reform offenders to control recidivism, containment to detect and prevent escape and jail break and promote prisoner's opportunities for social re-integration. Thus, the department has over the years implemented various models of rehabilitation and reintegration of offender. Planned interventions that endeavor to change the offender's cognitive processes, attitudes, personality or mental health is very essential. Broadly, rehabilitation refer to social relations with others, vocational skills, education and employment, which can be realized by inmates attending and completing various tests (Oketch, 2009). The intent of the intervention is to make the prisoners less likely to break the law in future or basically to reduce recidivism (Law, 2004). Maltz (1981) put forward that reintegration is the whole process through which an individual is reintroduced to the community with an aim of assisting the person to live in a law- should focus at promoting personal responsibility and providing prisoners with practical benefits to succeed in lawful occupation (KNCHR, 2010).

In Africa prison conditions are extremely bad, characterized by overcrowding, inadequate health and sanitation infrastructure, inexistence rehabilitation programme, insufficient food in terms of quality and quantity (KNCHR, 2003). According to Gaes (2008) the aim of any prison institution is to prevent and cure crime as such, there is no internationally recognized or accepted model of a prison system. The style of imprisonment is closely related to the culture and history of a country. The question of whether imprisonment does reform, correct, rehabilitate or reintegrate criminals is a question on which world authorities have not agreed (Becker, 2003). Although some offenders have been rehabilitated through imprisonment, what is known worldwide is that most prisons harden the offenders. What a sociologist can confirm is that some of the prison sentences contribute to the disintegration of some of the offenders' families and to the delinquency of their dependent minors thereby increasing the crime rate (Griffiths \& Murdoch, 2009). It's therefore a collective responsibility of every stakeholder to participate in the effort to reform the offenders. In the year 2001, Kenyan prisons reportedly embarked on reforming prison conditions.

Although there have been a few positive values of the rehabilitation reform, scholars have argued that it is more stated on paper than applied. When applied, it is not of a maximum rehabilitative value to the offender in particular and the wider community in general. The quality of the prison rehabilitation has therefore to be 
improved. Odegi (2001) have shown that prisons in Kenya have very limited and poor training facilities. For example, most of the industries and workshops do not have modern equipment and machines. Even in cases where these are, they are insufficient and very obsolete. The result is that prisoners come out half-baked because they get obsolete skills that are inadequate to compete in a world of sophisticated technology.

Abuyeka (2014) and Kenya National Human Rights Commission (KNHRC, 2005), blame the rise of crime and failure of rehabilitation of offenders in Kenya by prison officers on the shortcomings in the officers' work and living environment since the two are inseparable. A study by the KNHRC (2001) on prison conditions brought into sharp focus the inadequate housing for staff and inmates as the primary causes of squalid and inhuman conditions in prisons. In 2001, the UN special rapporteur on torture visited prisons in Kenya and compiled scathing report on prison conditions. Soon afterwards, reforms in prisons were commenced partly as a response to the recommendations made in the rapporteurs report. Overcrowding which is a visible case in Kenyan prisons, may act as an intensifier of stressful prison conditions occasioned by other factors with consequences that can threaten life. This challenge has been intensified by the lack of expansion of the prison system (Omboto, 2013). The second category of problems affecting the effectiveness of prisons is inherent with the prison organization itself. Prisons with limited infrastructural facilities, inmate training facilities and programs in the workshops and industries are bound to be ineffective. Though there has been reform interventions implemented in Kenyan prisons, the challenges has not been fully addressed considering insufficient staff housing, stores for staff and inmate, congestion of inmate, inadequate education programmes for prison fraternity which lead to re-offending, recidivism, jail escapes, riots hence hampering behavioral change (Ministry of Interior and Coordination, 2014). This echoing by the ministry led to formation of urgent committee comprising of probation officers to address the challenge of congestion in 2017 . Therefore this study sought to find out whether educational programmes reforms influences change of behavior of inmates in correctional facilities in Kenya.

\subsection{LITERATURE REVIEW}

Studies have shown that inmates can benefit in a number of ways when exposed to education, it can help those struggling with issues of self -worth, confidence and empowerment and that prisons arts programs contribute to inmate self-expression and exploration (Matarasso \& Chell, 1998: Jermyn, 2 001). An evaluation of prison education in Norway it contributes to inmate self-development through improving their motivation, social and life skills (Mushanga, 2006).

\subsection{Educational Programmes Reforms and Change of Behavior of Inmates in Correctional Facilities}

Numerous studies done by; Wilson and Kelling (2002); Kibui (2007); Schneider, Gruman \& Coutts (2012); Newman (1972) have revealed that vocational training, rehabilitation programs, education and prisoner therapy have a substantial outcome on improving the inmate, and the society as well as they are transformed into productive members of community. On average, the benefit reaped from rehabilitative programs by a society when compared funds spent on the programs is great. Therefore instead of depleting the economic resources, they can be increased exponentially by instilling relevant coping abilities and job skills to prisoners. By doing this, governments and stakeholders prepare prisoners to function normally instead of returning them to the streets, sometimes even more dangerous than they were before imprisonment (Schneider, Gruman, \& Coutts, 2012). Many inmates who have gone through rehabilitative programs have benefited a lot and some give back to the community in various ways as well as becoming mentors to those in need. Prison based college education programs demonstrates increased prospects for improved skills in solving problems, increased opportunity for employability, improved self-esteem, personal safety awareness and provision of manageable conditions within prison facilities (Contardo \& Tolbert, 2005). Hawley (2013) established that inmates who receive vocational training and general education are considerably less likely to be imprisoned again after release and are at a better position to get employment chances than those who did not access such opportunities. This notwithstanding, many prison facilities struggle to avail required scales of education. Education review in Europe revealed that amid the 640,000 prison populace European Union, a considerable proportion was composed of un-skilled or low-skilled persons. The Kenya Prisons service has developed a training curriculum which is in use at the prisons staff training college. There is need to constantly revise the curriculum to keep up to date with the emerging trends in penal issues and management. There is also need to expand facilities at the Prisons Staff Training College to accommodate more trainees and be able to mount senior management courses. There is a need for more investment in rehabilitative programs for adult inmates and juveniles convicted for trivial offenses and non-violent offenses, to enable returning money to the society, rather than taking it away, hence curb the crime cycle (Schneider, Gruman and Coutts, 2012). The organization of American States points to the multifaceted problems ailing the prison systems is marked by poorly trained personnel and prison officials as well as insufficient programmes in social reintegration and rehabilitation among others (Dammert and Zuniga, 2008). After conducting a comprehensive literature search, Sarkin (2009) did a meta-analysis to study the 
relationship of correctional education and reductions in recidivism, enhancements in employment upon release and effects on learning abilities. Findings of the study supported the evidence that receiving correctional education while imprisoned helps to reduce individual's risk of reoffending. The findings also disclosed that inmates receiving correctional education had improved likelihoods of procuring better jobs upon release. In examination of benefits of computer-assisted learning and costs of availing prison education programs as compared to the costs of re-incarceration, the impact of college education in prison on post-release outcomes was found to be great. The Gaes (2008) and Vacca (2004) argues that correctional education while confined reduces chances of recidivism and contributes significantly to enhancing employment prospects of formerly incarcerated persons.Creatively funding college education in correctional facilities, was to make accessible a cost-efficient educational programs by support of secure connections to internet (Spycher et al., 2012). Another way was by developing mentorship, problem-solving, and interpersonal skills building programs that is much needed for occupational and educational success while in prison and after release. Spycher et al. study is backed by Batiuket al. (2005) who put forward that confined men who earned an associate's degree were 62 percent less likely to reoffend and return to prison. The Government of Ghana realized the pressing need to explore alternative ways of addressing educational needs of her citizens. PSIDL open learning in vocational and technical education and training focused at equiping learners with relevant longterm skills while prison project targeted inmates preoccupied with acquisation of vital skills that would assist them to re-integrate into the community when released.In acknowledgement of the role of education in prisons, Asiedu (2001) suggested that prison authorities have a responsibility of providing inmates with facilities that promote formal and informal education within the prisons institutions. Asiedu (2001) further stressed that while prisoners could be incarcerated as punishment, all efforts done to reduce resentments and bitterness in prisoners is ultimately for the benefit of the large society to which they will return eventually. Programmes for social and civic education for communities may diminish in value, if prisoners are not considered in national efforts of general re-education. This is so because for prisoners, there is ample opportunity to reform and become better responsible citizens.Among the things that can be done to the Kenyan prisons staff is to basically reform the department. To ensure efficiency in rehabilitation and performance in prisons, it is crucial to make sure that prison officers are trained in relevant disciplines related to their work. When training for the job, the key function of rehabilitation and reformation calls for prison officers to accept that prisoners are only incarcerated as a punishment and not for punishment. Having done that, they gain the capacity to facilitate attitude and behaviour change. Professionals like professional counsellors, psychiatrists, religious leaders, sociologists, psychologists, social workers, criminologists and other social scientists need to be incorporated into prison service since such experts have the required skills and expertise to make positive changes in the human mind where criminality is fostered. Contrary to this expectation, many studies indicate that a good number of prisoners have attained college and university education which is lacking to most prison officers who are entrusted with providing solutions to prisoners challenges (Omboto, 2013).Training for prisoners in Kenya is made possible through the prisons Farms \& Industries Revolving Fund (PFIF) and vocation training programs. There is need for a distinction here. Under the PFIF, the prisoners undergo apprenticeship in workshops run supported by the revolving fund. Having attained a particular level of experience, the prisoners are enrolled for Government Trade Tests (GTT) offered by the Directorate of Training. The tests are paid for by the training vote under the PFIF allocations. Under the vocation training programs, Inmates undergo intensive instruction programs in artisan trades after which they sit for GTT. Funding for vocational programs is provided for under the prison`s current budget as well as donations from well-wishers. Prisoners who perform well enter into the prisons privilege system meant to encourage inmates to enroll for vocational courses. At the end of their jail terms, few graduates of the vocational program receive tool boxes to start-up business. The skills acquired may not be of much help because without start-up capital for business.

\subsection{Theoretical Framework}

The study was anchored on the following theories; theory of change developed by weiss (2000), theory of planned behavior and the unified theory of punishment by brooks (2015) the theories are suitable for study because they involve change, program and punishment respectively.

Theory of Planned Behavior

The theory' of reasoned action states that individual performance of a given behavior is primarily determined by a person's intention to perform that behavior (Ajzen, 1988). There are two major factors that shape the individual's attention. First, the individual's attitude towards the desired behavior must be positive for change to occur. Second, the influence of the person's social environment or subjective norm is another factor that shapes the individual's attention. This includes the beliefs of their peers and what they believe the individual should do as well as the individual's motivation to comply with the opinions of their peers. The theory of planned behavior includes the concept of perceived control over the opportunities, resources, and skills necessary' to perform the desired behavior. The concept of Perceived behavioral control is similar to the concept of self-efficacy. A vital aspect of this theory helps us to understand how we can change the behavior of people. The TPB is a theory 
which predicts deliberate behavior, because behavior can be planned.

According to TPB theory, human behavior is guided by behavioral beliefs which are the are beliefs about the likely consequences of the behavior, normative beliefs which are beliefs about the normative expectations of others and control beliefs which are beliefs about the presence of factors that may facilitate or may impede, the performance of the behavior. The three considerations are crucial in circumstances of projects or programs when the behavior of people needs to be changed. In their respective aggregates, behavioral beliefs produce a favorable or unfavorable attitude toward the behavior, normative beliefs result in perceived social pressure or subjective norm, and control beliefs give rise to perceived behavioral control. In combination, the attitude toward the behavior, subjective norm, and perception of behavioral control, leads to the formation of a behavioral intention (Ajzen, 1988). As a general rule, if the attitude and subjective norm are more favorable, the perceived control will be greater, and the persons intention to perform the behavior in question should be stronger. The theory of planned behavior can help to explain why campaigns that aim at attitude, perceived norms and control in making the change or buying certain goods, have better results. Similarly in management, programs that focus only on explanation of the importance of something (knowledge transfer) will likely not succeed. Rather one should convince people to change behavioral change process is perceived behavioral control over opportunities, resources, and skills necessary to perform a behavior (Ajzen, 1988). This theory helps to understand how to change the behavior of people. The TPB is a theory which predicts deliberate behavior, because behavior can be planned. According to TPB theory, human behavior is guided by behavioral beliefs which are the are beliefs about the likely consequences of the behavior, normative beliefs which are beliefs about the normative expectations of others and control beliefs which are beliefs about the presence of factors that may facilitate or may impede, the performance of the behavior

\subsection{Conceptual Framework Independent Variable}

\section{Dependent Variable}

\begin{tabular}{|c|c|}
\hline $\begin{array}{l}\text { EDUCATIONALPROGRAMMES } \\
\text { - Access to primary education } \\
\text { - Access to secondary education } \\
\text { - Availability of training materials } \\
\text { - Vocational and professional training } \\
\text { - Availability of trainers }\end{array}$ & $\begin{array}{l}\text { CHANGE OF BEHAVIOR OF } \\
\text { INMATES } \\
\text { - Increase or decrease in; } \\
\text { - Re-offending } \\
\text { - Recidivism } \\
\text { - Jail breaks } \\
\text { - Riots and unruly habits } \\
\text { - Escapes while in prisons }\end{array}$ \\
\hline
\end{tabular}

\subsection{RESEARCH METHODOLOGY}

Pragmatism is viewed as a deconstructive paradigm that backs the use of mixed methods in research, a paradigm that circumvents the contention in reality and truth and instead directs focus on 'what is plausible' as the truth concerning the research questions being investigated (Biesta, 2010). The shift of researchers to mixed methods approach showed research designs that adopted "mixing" of quantitative or qualitative approaches when gathering data of a study for instance This study adopted causal comparative research designs and descriptive cross-sectional survey. The cross-sectional survey design incorporates qualitative and quantitative approaches. The quantitative approach consists of closed-ended questions which will prompt information for inferential and descriptive purposes. The qualitative approach with open-ended questions obtained in-depth information to validate inferential and descriptive results (Mwanje, 2001). Across-sectional survey design is argued to be cheaper than longitudinal designs hence they are most appropriate for academic investigators, who in most cases work under strict budget responses rather than ones that reflect their own true opinions (ASA, 1999; Rindfleisch et al., 2008).

Uma (2003) defines a target population as the actual hypothetical set of events, people or objects which the researcher sought to generalize the findings. There were 9 prison institutions in Nairobi County, Kenya with a total target population of 10,111 individual which was spread as 7,158 prisoners and 2,953 prison officers (including 9 officers in-charge, 9 deputy officers in-charge) who formed the population of this study. The sample was gotten from the population using formula. This decision was based on Cooper and Schindler (2003) regarding the need to purposely include elements in a population in a study, to gather appropriate data for a particular study prison institution. They were arranged alphabetically and selected randomly from the list.

The study sought both primary and secondary data. In this regard, three sets of instruments were applied to source requisite data, including a survey questionnaire, an interview schedule and focus group discussion. The application of multiple instruments is important for enhancing validity of data obtained and minimizing the possibility of experiencing interviewer biases. Such biases often arise from non-verbal cues that may influence 
participants to give misleading responses by reporting positive aspects even where negative aspects are predominant (Jaeger, 1984). The study applied a questionnaire that targeted inmates who were informed about the study and consented to ensure voluntary participation. The instrument contained closed-ended and openended questions structured according to objectives of the study. The questionnaire was structured into two parts. Part 1 details the demographic information, part 2 is divided into three sections $\mathrm{A}, \mathrm{B}$ and $\mathrm{C}$ that captures the two variables of the study.

The instrument captures information that meets the requirements for positivistic paradigm and quantitative approach. The information captured in the simplest variable forms was the objective and used to confirm or refute hypothesized influence of prison reforms on performance of prison facilities. An interview schedule were applied on officers' in-charge and their deputies who are key informants. The investigator sought consent from officer's in-charge and deputy officer's in-charge and booked appointments which was to be used to develop a data collection itinerary. Participants were given an outline of the topics that were discussed at least a day earlier to ensure constructive deliberations. The tool was sought information on the educational programmes reform and change of behavior of inmates. As noted by Touliatos and Compton (1988), evaluating perceptions, views, attitudes, opinions and feelings of individuals can done best through in-depth interview schedules. Focus discussions are a form of group interviews that capitalize on sharing information between facilitators and participants so as to generate data (Best \& Khan, 2004). Mugenda (2010) view focus group technique as a research method that gathers information through interaction of members of a group on a particular topic that the chosen by the investigator; the interest of investigator guides the focus while the information emanates from group interactions (Morgan, 1997). Though group interviews are frequently used as a convenient and quick way to gather data from numerous people concurrently, focus groups explicitly utilize interactions by groups as part of the method (Creswell, 2008). In this study, FGD guide targeted prison officers in different prisons. A group comprising of twelve officers will be formed and questions raised from the variables of study will be raised and discussed.

Recruited research assistants were guided by the investigator to aid in collecting data. To enhance familiarity with the instrument, the researcher held training sessions with research assistants who also refreshed them on research ethics, enable sharing of essential data sourcing skill especially on the right approach to participants and building rapport with the respondents. Data collection commenced on approval of relevant authorities such as the commissioner general of prison and also acquire a authorization to carry on research from the National Commission for Science and Technology (NACOSTI).

Both quantitative and qualitative approaches were applied in processing, analyzing, and interpretation of the data. Quantitative data processing involves coding close-ended data, cleaning, entry, transformation, analyzing and interpretation (Obure, 2002). To generate percentages, frequency distributions, and measures of central tendency, the SPSS programme was used to run analysis. In addition, charts, graphical presentations and tables were produced. Descriptive and regressions were run especially to assess the relationship among independent variable and dependent variable. To test for hypothesis one; $\mathrm{H}_{0} 1$ : There is no significant relationship between educational programme reforms and change of behavior of inmate in correctional facilities in Nairobi County, Kenya.

Regression analysis by Alexopoulos (2010) was run.

$Y=a+B X+\varepsilon$

Where;

$\mathrm{Y}=$ change of behavior of inmates in correctional facilities

$\mathrm{a}=$ constants/Intercept

$\beta=$ Coefficient,

$\mathrm{X}=$ educational programmes

$\varepsilon=$ Error term

Coefficient $\beta$ denote the change of behavior of inmates in correctional facilities from a change in educational programmes reform. Relationship exists if the regression coefficient $(\beta)$ is statistically significant

\subsection{FINDINGS}

This chapter presents the study results which have been discussed based on thematic and sub-thematic areas of study objectives. Thematic areas are idealized as educational programmes and change of behavior of inmates in correctional facilities. Both quantitative and qualitative approaches were applied in processing, analyzing, and interpretation of the data. To generate percentages, frequency distributions, and measures of central tendency, the SPSS programme was used to run analysis. In addition, charts, graphical presentations and tables were produced. Descriptive and multiple regressions were run to assess the relationship among independent variables and dependent variable. The qualitative data was processed and analyzed in three steps. First, data was organized and summarized in accordance to study objectives. Secondly, description of the summary sheets in order to produce a preliminary report was done. Data was collected through focus group discussion, questionnaire and 
informant interview schedule and were presented as per respective thematic areas.

Out of the 273 questionnaires administered to inmates, 233 were dully filled giving a response rate of $85 \%$. Out of 108 prison officers targeted for focus group discussion, 99 were available and fully took part in the discussion, representing a response rate of $92 \%$, while out of 4 officers in-charge and theirs deputies reached out for interview were all available and participated giving a response rate of $100 \%$ and therefore all these response were regarded as the responsive instrument for subsequent analysis. This was in line with the views of Cooper and Schiendler (2005) who observes that $75 \%$ and above response rate is reasonable enough for statistical generalization.In order to understand the characteristics of prisoners category respondents, the researcher was dealing with in the study, their background information was necessary, especially in relation to prison facilities in which the respondents were held. The study sought to elicit first information from the respondents on distribution by gender, age, number of years imprisoned, academic qualification section deployed. These are further discussed in the following sub sequent sub-themes. The demographic characteristics of the prisoners that were considered by the study were facilities, gender, age group, level of education, length of jail term in the prison facility. Distribution by facility was important to check capacity or whether the facilities were overstretched or if respondents were evenly distributed across the facilities under consideration. Distribution of respondents by gender was done to ascertain that the nature of institutional reforms was in tandem with the specific needs of respondents and that none of the two genders was given preferential consideration in the selection of the respondents. Distribution of respondents by age group was done to ascertain that respondents held were of majority age and the minors were held in institutions where institutional reforms were tailor made to suit their needs. Distribution of respondents by level of education was considered important because level of education would most likely have impact on usefulness of institutional reform designed for each level of prisoners, and the type of personnel requirement to needed to train and impact the required skills to each category.

Table 4.1 Means and standard deviation for inmates change of behavior in correctional facilities

\begin{tabular}{|c|c|c|c|c|c|}
\hline Statement & $\mathbf{N}$ & Min & Max & Mean & $\begin{array}{l}\text { Std. } \\
\text { Deviation }\end{array}$ \\
\hline $\begin{array}{l}\text { The number of riots by inmates has increased since the } \\
\text { prison reforms were initiated in } 2002\end{array}$ & 233 & 1 & 5 & 2.13 & 1.242 \\
\hline $\begin{array}{l}\text { The number of unruly behavior cases has satisfactory } \\
\text { increased since the prison reform were initiated in } 2002\end{array}$ & 233 & 1 & 5 & 2.24 & 1.187 \\
\hline $\begin{array}{l}\text { The number of re-offending within prison has been } \\
\text { satisfactorily addressed }\end{array}$ & 233 & 1 & 5 & 3.07 & 1.065 \\
\hline $\begin{array}{l}\text { Timely reporting of case emanating from prison has } \\
\text { improved satisfactory }\end{array}$ & 233 & 1 & 5 & 3.30 & 1.089 \\
\hline $\begin{array}{l}\text { Jailbreaks has increased since inception of reforms in prison } \\
\text { for the last ten years }\end{array}$ & 233 & 1 & 5 & 2.20 & 1.308 \\
\hline $\begin{array}{l}\text { The number of prison who have escaped from prison have } \\
\text { increased satisfactory since the last ten years }\end{array}$ & 233 & 1 & 5 & 2.18 & 1.304 \\
\hline $\begin{array}{l}\text { The number of inmate facing multiple cases in court have } \\
\text { increased drastically }\end{array}$ & 233 & 1 & 5 & 2.57 & 1.116 \\
\hline $\begin{array}{l}\text { The number of inmate who have committed offence again } \\
\text { after release have increased }\end{array}$ & 233 & 1 & 5 & 2.39 & 1.255 \\
\hline $\begin{array}{l}\text { The death cases resulting from riots has significantly } \\
\text { reduced }\end{array}$ & 233 & 1 & 5 & 3.66 & 1.308 \\
\hline $\begin{array}{l}\text { The number of fight within the prison has increased since } \\
\text { the prison reform were initiated in } 2002\end{array}$ & 233 & 1 & 5 & 2.19 & 1.074 \\
\hline \multirow[t]{2}{*}{ The general living conditions in prisons has improved } & 233 & & & & \\
\hline & & 1 & 5 & 3.53 & 1.390 \\
\hline Composite mean & 233 & 1 & 5 & 2.68 & 1.219 \\
\hline
\end{tabular}

The research findings in table 4.5 showed that the mean score for the indicators used to measure inmate's change of behavior was 2.68 and standard deviation of 1.219 . The study revealed a moderate agreement with the sentiment in each question item $M(=2.68)$. Based on individual questionnaires item responses, the results showed that to a great extent, respondents disagreed the number of riots by inmates has increased since the prison reforms were initiated in $2002(\mathrm{M}=2.13, \mathrm{SD}=1.242)$. The number of unruly behavior cases has increased since the prison reform were initiated in $2002(\mathrm{M}=2.24, \mathrm{SD}=1.187)$. The number of re-offending within prison has been satisfactorily addressed $(\mathrm{M}=3.07, \mathrm{SD}=1.065)$. Timely reporting of case emanating from prison has improved satisfactory $(\mathrm{M}=3.30, \mathrm{SD}=1.089)$. Jailbreaks has increased since inception of reforms in prison for the last ten years $(\mathrm{M}=2.20, \mathrm{SD}=1.308)$. The number of prison who have escaped from prison have increased satisfactory since the last ten years $(\mathrm{M}=2.18, \mathrm{SD}=1.304)$. 
The number of inmate facing multiple cases in court have increased drastically $(M=2.57, \mathrm{SD}=1.116)$. To a moderate extent, the number of inmates who have committed offence again after release have increased drastically $(\mathrm{M}=2.39, \mathrm{SD}=1.255)$. Agreed that death cases resulting from riots has significantly reduced $(\mathrm{M}=3.66$, $\mathrm{SD}=1.308)$. Disagreed that the number of fight within the prison has significantly increased since the prison reform were initiated in $2002(\mathrm{M}=2.19, \mathrm{SD}=1.074)$. Agreed that the general living conditions in prisons has satisfactorily improved $(\mathrm{M}=3.53, \mathrm{SD}=1.390)$.

\section{Means and standard deviation for educational programmes}

Items were rated as strongly agree (5) to strongly disagree (1). A score of $\leq 1.5$ was interpreted to mean strongly disagree, while a score 1.5 to $\leq 2.5$ implied that the respondents disagrees and 2.5 to $\leq 3.5$ was interpreted to mean that the respondent was neutral. A mean score of $3.5 \leq 4.5$ was interpreted to mean that respondents agree while a score of $\geq 4.5$ was interpreted to mean strongly agree. A standard deviation of $\leq 1$ was interpreted to mean that respondents had a consensus in the rating of the statement while a standard deviation greater than 1 was interpreted to mean that the respondents differed in their perception about the statement.

Table 4.2: Means and standard deviations for educational programmes

\begin{tabular}{|c|c|c|c|c|c|}
\hline Statement & $\mathbf{N}$ & Min & Max & Mean & $\begin{array}{l}\text { Std. } \\
\text { Deviation }\end{array}$ \\
\hline \multicolumn{6}{|l|}{ There is unrestricted access to primary education } \\
\hline & 233 & 1 & 5 & 3.73 & 1.279 \\
\hline \multirow{3}{*}{$\begin{array}{l}\text { There are adequate trained teachers to guide the } \\
\text { learners on primary education curriculum } \\
\text { There is unrestricted access to secondary education }\end{array}$} & & & & & \\
\hline & 233 & 1 & 5 & 3.18 & 1.314 \\
\hline & 233 & 1 & 5 & 3.18 & 1.314 \\
\hline $\begin{array}{l}\text { Prison institution have a framework on policies about } \\
\text { forms of secondary education }\end{array}$ & 233 & 1 & 5 & 3.22 & 1.301 \\
\hline \\
\hline \multicolumn{6}{|l|}{$\begin{array}{l}\text { Professional training are recognized as part of } \\
\text { rehabilitation programs in prison }\end{array}$} \\
\hline \multicolumn{6}{|c|}{ There is availability of adequate trainers on } \\
\hline \multicolumn{6}{|c|}{ There is availability of adequate trainers on } \\
\hline \multicolumn{6}{|l|}{ Learning and training materials are adequately } \\
\hline \multicolumn{6}{|l|}{$\begin{array}{l}\text { Education certificate awarded to inmates while in } \\
\text { prison does not indicate in any way that the inmate }\end{array}$} \\
\hline \multicolumn{6}{|l|}{ Learning facilities that are conducive are provided } \\
\hline & 233 & 1 & 5 & 2.83 & 1.314 \\
\hline Composite mean & 233 & 1 & 5 & 3.21 & 1.302 \\
\hline
\end{tabular}

The research findings in Table 4.17 showed that the mean score for the eleven statements for education program reforms was 3.21 and standard deviation of 1.302. From individual items' mean and standard deviation, it was clear that the respondents either agreed or disagreed with the state of education program reforms in the facilities. Agreed that there is unrestricted access to primary education $(\mathrm{M}=3.73, \mathrm{SD}=1.279)$, moderately agreed that there are adequate trained teachers to guide the learners on primary education curriculum $(\mathrm{M}=3.18$, $\mathrm{SD}=1.314)$, moderately agreed on unrestricted access to secondary education $(\mathrm{M}=3.18, \mathrm{SD}=1.314)$, agreed on prison institution having a framework on policies about forms of secondary education $(\mathrm{M}=3.22, \mathrm{SD}=1.301)$. Were in agreement that vocational training are recognized as part of rehabilitation programs in prison $(\mathrm{M}=3.63$, $\mathrm{SD}=1.337$ ), moderately agreed that professional training are recognized as part of rehabilitation programs in correctional facilities $(\mathrm{M}=3.17, \mathrm{SD}=1.270)$, and disagreed that there is availability of adequate trainers on vocational courses $(\mathrm{M}=2.83, \mathrm{SD}=1.314)$ and disagreed that there is availability of adequate trainers on professional courses $(\mathrm{M}=2.97, \mathrm{SD}=1.273)$. They disagreed that learning and training materials are adequately provided $(\mathrm{M}=2.80, \mathrm{SD}=1.331)$, were in disagreement that learning facilities that are conducive for learning are provided $(\mathrm{M}=2.83, \mathrm{SD}=1.314)$ however, they agreed that the certificate awarded to inmates while in prison does not indicate in any way that the inmate has been institutionalized $(\mathrm{M}=3.73, \mathrm{SD}=1.279)$.

The overall mean and standard deviation $(\mathrm{M}=3.21, \mathrm{SD}=1.302)$, implied that the respondents had responses that were scattered around the mean. They either agreed or disagreed regarding the issues raised through the 
questionnaire, hence their responses concentrated around the mean. These research findings implied that education program reforms is a major issue in correctional facilities reforms that need to be wholly addressed in order to have great impact on change of behavior of inmates in correctional facilities.

Correlation analysis of educational programmes and change of inmate's behavior in correctional facilities Correlational analysis using Pearson's Product Moment technique was done to determine the relationship between educational programmes and change of inmate's behavior in correctional facilities. It was meant to identify the strength and direction of the association between the independent and dependent variable. The results are summarized in Table 4.3.

Table 4.3: Correlation table for educational programmes and change of inmate's behavior

\begin{tabular}{lll}
\hline Educational Reform & \\
\hline Change of Behavior of Inmates & Pearson correlation & $0.425^{* * *}$ \\
Sig (2-tailed) & & 0.000 \\
& $\mathrm{~N}$ & 233 \\
\hline
\end{tabular}

** correlation is significant at the 0.01 level (2-tailed)

The correlation results in Table 4.18 indicated a correlation of 0.429 and a significance of 0.000 (two tailed test), implying a positive and significant coefficient. The results indicated presence of moderate positive and significant relationship between educational programmes and change of inmates behavior in correctional facilities in Nairobi county, Kenya $(r=0.429$, $\mathrm{p}$-value $<0.01)$. Therefore, education programmes said to have a positive moderate and significant relationship with change of inmate's behavior in correctional facilities.

Inferential analysis of influence of educational programmes on change of inmate's behavior in correctional facilities

The objective of the study was to determine the extent to which educational programmes influences change of inmate's behavior in correctional facilities in Kenya. The literature and empirical evidence had suggested that educational programmes influences change of inmate's behavior in correctional facilities. Change of inmate's behavior in correctional facilities was the dependent variable in the study and had five indicators namely; Reoffending, recidivism, jail breaks, riots and unruly habits, escapes while in prisons.

Educational programmes in correctional facilities was the independent variable in the study. Data was collected using eleven items that was measured on a five-point Likert scale. A composite index was computed and used in testing the hypothesis. To satisfy the objective, the following hypothesis was tested using simple linear regression model.

\section{Hypothesis}

To test for hypothesis; $\mathbf{H}_{0}$ : There is no significant relationship between educational programmes and change of behavior of inmate in correctional facilities in Kenya.

$Y=a+B X+\varepsilon$ Where; $\mathrm{Y}=$ change of behavior of inmates in correctional facilities

$\mathrm{a}=$ constants/Intercept $\beta$, =Coefficient

$\mathrm{X}=$ educational programmes $\varepsilon=$ Error term

The results were presented in Table 4.4 .

Table 4.4: Regression results of influence of educational programmes on change of behavior of inmate in correctional facilities

\begin{tabular}{|c|c|c|c|c|c|}
\hline \multirow[t]{2}{*}{ Model } & \multicolumn{2}{|c|}{$\begin{array}{l}\text { Unstandardized } \\
\text { Coefficients }\end{array}$} & \multirow{2}{*}{$\begin{array}{l}\text { Standardized } \\
\text { Coefficients } \\
\text { Beta } \\
\end{array}$} & \multirow[t]{2}{*}{$\mathbf{t}$} & \multirow[t]{2}{*}{ P-Value } \\
\hline & B & Std.Error & & & \\
\hline Constant & 2.550 & 0.144 & & 11.689 & 0.000 \\
\hline $\begin{array}{l}\text { Educational } \\
\text { Reforms }\end{array}$ & 0.307 & 0.051 & 0.425 & 7.129 & 0.000 \\
\hline \multicolumn{6}{|c|}{$\begin{array}{l}\text { Predictors:(Constant) Educational Programmes } \\
\text { Dependent Variable Change of Behavior of Inmates }\end{array}$} \\
\hline $\begin{array}{l}R=0.425 \\
R \text { square }=0 . \\
t=7.129 \text { at le }\end{array}$ & ignifi & $p=0.000$ & & & \\
\hline
\end{tabular}

The study findings in Table 4.4 showed that $r$ was equal to 0.425 , indicating that educational programmes $r$ 
had a moderately strong influence on change of behavior of inmate in correctional facilities. The value of $\mathrm{r}^{2}$ was 0.180 , indicating that educational programmes explained $18 \%$ of the variation in change of behavior of inmate in correctional facilities. The $\beta$ coefficient was 0.425 , indicating that educational programs reform had statistically significant influence on change of behavior of inmate in correctional facilities $(\beta=0.425, t=7.129$, $p=0.000<0.05)$. Considering the $p$ value, it can be noted that the $p$ value for educational programmes $(p=0.0000)$ was statistically significant. The $\beta$ value implied that one unit change in behavior of inmates in correctional facilities was associated with $42.9 \%$ changes in educational programmes.

The overall $\mathrm{t}=7.129$ with $\mathrm{p}=0.000<0.05$ suggested that there was a statistically significant relationship between education programs reform and change of behavior of inmate in correctional facilities in Kenya. Based on the research findings the alternate hypothesis was accepted which stated that there is a significant relationship between educational programmes and change of behavior of inmate in correctional facilities in Kenya and concluded that educational programmes had a statistically significant influence on change of behavior of inmate in correctional facilities in Nairobi County, Kenya.

Using the statistical findings, the regression model was substituted as follows

$\mathrm{Y}=2.550+0.425 \mathrm{X}+\varepsilon$

Where; $Y=$ change of behavior of inmates in correctional facilities

$a=$ constants/Intercept $\beta=$ Coefficient $X=$ educational programmes $\varepsilon=$ Error term

Findings from this study agreed with Kibui (2007); Schneider, Gruman and Coutts (2012) that well managed education programmes in correctional facilities was directly attributed to change of inmates behavior. Findings were also in line with Hawley (2013) who argued that to a large extent improved education programs has an influence on behavior change since the level of knowledge and exposure of an individual contribute largely to how they behave and conduct themselves

\section{CONCLUSIONS}

$r$ was equal to 0.425 , indicating that educational programmes $r$ had a moderately strong influence on change of behavior of inmate in correctional facilities. The value of $r^{2}$ was 0.180 , indicating that educational programmes explained $18 \%$ of the variation in change of behavior of inmate in correctional facilities. The $\beta$ coefficient was 0.425 , indicating that educational programs reform had statistically significant influence on change of behavior of inmate in correctional facilities

\section{RECOMMENDATIONS}

Considering the government of Kenya as well as many other developing countries were gearing towards implementation of reforms that will ensure correctional facilities are run in humane manner putting into consideration international standards. This study has implication to government implication agencies and especially ministry of interior and coordination of national government in which the prison department is placed. Study findings indicated that educational programmes had an influence on change of behavior of inmates in correctional facilities in Kenya.

\section{REFERENCES}

Abuyeka, R. O. (2014). Inmates' and Warders' Perception of Prison Reforms in Kenya: A Case of EldoretGk Prison, in Eldoret, Kenya. Public Policy and Administration Research, Vol. 4(11),17-20.

Achu, A., Owan, E. J., \& Ekok, O. C. (2013). The impact of prison reform on the welfare of Inmates. A case study of Afonkong prison Calabar, Cross River State, Nigeria. Global Journal of Human social science sociology and culture, 13,1-7.

Adler, M., \& Longhurst, B. (1994). Discourse, power and justice: Towards a new sociology ofimprisonment. Routledge. London.

Adlerstein, D. M. (2001). In Need of Correction: The "Iron Triangle" of the Prison Litigation Reform Act. Columbia Law Review, Vol. 101(7), pp. 1681-1708.

Alexopoulos, E. C. (2010). Introduction to Multivariate Regression Analysis.Quarterly Medical Journal,14(1), 23-28.

Anderson, K., \& Overy, K. (2010). Engaging Scottish young offenders in education through music and art.International Journal of Community Music, 3,1.

Aos, S., Miller, M., \& Drake, E. (2006). Evidence-Based Adult Corrections Programs: What Works and What Does Not. Washington State Institute for Public Policy

Aosa, E. (1992). An Empirical Investigation of Aspects of Strategy Formulation and Implementation within Large Private Manufacturing Companies in Kenya-Unpublished PhD Thesis, University of Strathclyde Glasgow Scotland U.K

Armenakis, A. (2002). Crafting a change message to create transformational readiness. Oxford, Oxfam.

Arts Education Partnership (2004).the arts and education: New opportunities for research,. 
Best, J. W., \& Kahn, J. V. (2003).Research in Education. Boston: Library of congress cataloguing in publication data.

Bhalerao C. N. (2000). Urgent Need for Prison Reforms.Economic and Political Weekly, Vol. 35(10), p. 746751.

Biesta, G. (2010). Pragmatism and the philosophical foundations of mixed methods research. Handbook of mixed methods research for the social \& behavioral sciences, 2nd ed. Thousand Oaks, CA: SAGE

Blacker, J., Watson, A. \& Beech, A. R. (2008). A Combined Drama-Based and CBT Approach to Working with Self-Reported Anger Aggression. Crimina lBehavior and Mental Health,18,12937.

Blank, R. (1993). Developing a system for education indicators; selecting, implementing and reporting indicators. Educational evaluation and policy analysis, 15(1),65-80

Blumberg, B., Cooper, D. R., \& Schndler, P. S. (2005).Business Research Methods. London. McGraw-Hill Inc

Borg, W.R., \& Gall, M. D. (1989). Educational research: an introduction, 5th ed. White Plains, NY: Longman

Cohen, M. L. (2009). Choral Singing and Prison Inmates: Influences of Performing in a Prison Choir. The Journal of Correctional Education,60(1),52-65.

Cole, S. (2002). Criminological Theories. London: International Educational and Professional Publisher.

Contardo, J., \& Tolbert, M. (2005). Prison Postsecondary Education: Bridging Learning from Incarceration to the Community. John Jay College of Criminal Justice

Cook, T. D., \& Campbell, D.T. (1999). Quasi-Experimentation: Design \& Analysis Issues for Field Settings. Boston: Houghton Mifflin Company

Cooper, D. R., \& Schndler, P. S. (2008). Business Research Methods. 8th. ed. Tata McGraw, India

Cousins, J. B., \& Earl, L. M. (2009). When The Boat Gets Missed: Response To M.F. Smith. American Journal of Evaluation, 20, 309- 317.

Franklin, E. Z., \& David, L. R. (2008). Prison policy reform. Issues in Science and Technology, Vol. 25(1), pp 72-90

Gaes, G. G. (2008). The Impact of Prison Education Programs on Post-Release Outcomes. Reentry Roundtable on Education.

Gay, L. R. (1996). Educational research: Competencies for analysis and application. (5thEd.). Englewood Cliffs, NJ: Prentice-Hall.

Gehring, T. (2007). International Perspectives in Correctional Education. Journal of Correctional Education, Vol. 58(2), p. 213

Gude, O. (2009). Art Education for a Democratic Life. Lowenfeld Lecture presented at the National Art Education Association National Convention, Minneapolis,

Isaac, S., \& Michael, W. (2002). Handbook in Research and Evaluation: For Education and the Behavioral Sciences. San Diego: Ed. ITS Publishers

Jaeger, R. (1984). Sampling for Education and the Social Sciences. White Plains, New York: Longman.

Jermyn, H. (2001). The Arts and Social Exclusion: A Review Prepared for the Arts Council of England

Jewkes, Y., \& Letherby, G. (2002). Criminology: A Reader. New Delhi: Sage Publication.

Kiira, J. J. (2014). Judges behind bars: the intrusiveness requirement's restriction on the implementation of relief under the prison litigation reform act. Columbia Law Review, Vol. 114(3), pp. 715-754

Koech, J. K. (2009). The Effect of Open Door Policy on Service Delivery in Prisons, Independent Paper, Day Star University

Kothari C. R. (2005). Research Methodology: Methods and Technology, New Age International Publishers

Krumholz, H., \& Herrin, J. (2010). Quality improvement: the need is there but so are the challenges. American Journal of Medicine, 109, 501-503.

MacCormick, G. (2007). Historical vignette: Toothbrush as a Tool for Prison Reform and Correctional Education. Journal of Correctional Education, Vol. 58, (1), 26

Omoni, G. E., \& Ijeh, S., U. (2009). Qualitative Education for Prisoners: A Panacea to Effective Rehabilitation and Integration into the Society. Edo Journal of Counselling, 2(1) 30-31.

Ross, J., \& Gangi, R. (2009). Education from the Inside, Out: The Multiple Benefits of College Programs in Prison. Correctional Association of New York

Silber, L. (2005). Bars Behind Bars: The Impact of a Women's Prison Choir on Social Harmony," Music Education Research, 7(2),251-271.

Steurer, S., \& Smith, L. G. (2003). Education Reduces Crime: Three-State Recidivism Study Executive Summary. Lanham, MD: Correctional Education Association and Management \& Training Corporation Institute

Steve, M. (2003). Maconochie's Gentlemen: The Story of Norfolk Island and The Roots of Modern Prison Reform. The British Journal of Criminology, Vol. 43(4), 825-826

Susan, N. H. (2012). Assessing the Impact of the 1996 Reforms. Prisoner Rights and Habeas Corpus: Federal 
Sentencing Reporter, Vol. 24, (4), pp. 263-267

Susskind, R. (2004). Transforming the Law: Essays on Technology, Justice, and the Legal Marketplace, New York: Oxford University

Terry, L. (2011). Leap, Phantom Billing, Fake Prescriptions, and the High Cost of Medicine: Health Care Fraud and What to do about It. Cornell University Press, 2011.

Theresa, R. J. (2000). Reform versus Reality in the Progressive Era Texas Prison

Thom, G. (2007). Historical Vignette. Journal of Correctional Education, Vol.58 (1), p. 68

Touliatos, J., \& Compton, N. H. (1988). Research methods in human ecology/home economics. Iowa State University Press (Ames)

Uma, S. (2003).Research Methods For Business, A Skill-Building Approach, Fourth Edition. Southern Illinois University at Carbondale. John Wiley \& Sons, Inc

Vacca, J. S. (2004). Education Prisoners Are Less Likely to Return to Prison. Journal of Correctional Education, 55(4): 297-305 